\title{
Serum amyloid A circulating levels and disease activity in patients with juvenile idiopathic arthritis
}

\author{
L Cantarini ${ }^{1 *}$, MG Brizi ${ }^{1}$, G Simonini ${ }^{2}$, T Giani ${ }^{2}$, A Vitale ${ }^{1}$, A Fioravanti ${ }^{1}$, MR Bacarelli ${ }^{1}$, Galeazzi Mauro ${ }^{1}$, R Cimaz $^{2}$ \\ From 18th Pediatric Rheumatology European Society (PReS) Congress \\ Bruges, Belgium. 14-18 September 2011
}

\section{Background}

Serum amyloid A (SAA) has been shown to correlate with disease activity in ankylosing spondylitis, and its superiority to erythrocyte sedimentation rate (ESR) and $\mathrm{C}$-reactive protein (CRP) has been suggested.

\section{Objective}

Our aim was to evaluate the association SAA circulating levels and disease activity in patients with juvenile idiopathic arthritis (JIA)

\section{Methods}

Our study group included 41 JIA patients (9 male, 32 female), classified according to the ILAR criteria; 16 had polyarticular disease and 25 had oligoarticular disease; $3 / 25$ patients with oligoarticular diseases had extended oligoarthritis. Serum SAA, ESR and CRP were measured both in patients and 26 healthy controls.

\section{Results}

SAA levels were higher in JIA patients versus healthy controls $(p<0.001)$. Significant positive correlations were found between SAA and the presence of active joints $(\mathrm{p}<0.05)$, the number of active joints $(\mathrm{p}<0.05)$, ESR $(\mathrm{p}<0.05)$ and CRP $(\mathrm{p}<0.05)$. No significant correlations between ESR and the presence of active joints $(\mathrm{p}=0.225)$ or between ESR and the number of active joints $(\mathrm{p}=0.520)$ were demonstrated in JIA patients. No significant correlations were obtained between CRP and the presence of active joints $(\mathrm{p}=0.855)$, or between CRP and the number of active joints $(\mathrm{p}=0.859)$.

'Rheumatology Unit, Department of Clinical Medicine and Immunologic Sciences, University of Siena, Italy

Full list of author information is available at the end of the article

\section{Conclusion}

We found a significant increase of SAA levels in JIA patients as compared to controls, and a strong positive correlation between SAA level and JIA disease activity. We also determined SAA to be a more sensitive laboratory marker than ESR or CRP when compared with the presence and with the number of active joints. We suggest that SAA can be used as an additional indicator of disease activity in JIA.

\section{Author details}

${ }^{1}$ Rheumatology Unit, Department of Clinical Medicine and Immunologic Sciences, University of Siena, Italy. ²Department of Paediatrics, Rheumatology Unit, Anna Meyer Children's Hospital and University of Florence, Italy.

Published: 14 September 2011

doi:10.1186/1546-0096-9-S1-P315

Cite this article as: Cantarini et al: Serum amyloid A circulating levels and disease activity in patients with juvenile idiopathic arthritis. Pediatric Rheumatology 2011 9(Suppl 1):P315.

Submit your next manuscript to BioMed Central and take full advantage of:

- Convenient online submission

- Thorough peer review

- No space constraints or color figure charges

- Immediate publication on acceptance

- Inclusion in PubMed, CAS, Scopus and Google Scholar

- Research which is freely available for redistribution

\section{() Biomed Central}

